\title{
MAPPING GEOSITES AS GATEWAYS TO THE GEOTOURISM MANAGEMENT IN CENTRAL HIGH-ATLAS (MOROCCO)
}

\author{
Hicham Bouzekraoui ${ }^{1,2^{*}}$, Ahmed Barakat ${ }^{2}$, Mohammed El Youssi ${ }^{1}$, Fatima Touhami ${ }^{3}$, \\ Atika Mouaddine ${ }^{4}$, Abdellatif Hafid ${ }^{5}$, Zigigniew Zwoliński ${ }^{6}$ \\ ${ }^{1}$ Team of Geotourism and Desertic Environments, Faculty of Sciences, Mohammed V University of Rabat, \\ Rabat, Morocco \\ ${ }^{2}$ Georessources and Environment Laboratory, Faculty of Sciences and Techniques, Sultan Moulay Slimane \\ University, Béni-Mellal, Morocco \\ ${ }^{3}$ Interdisciplinary Laboratory of Research in Sciences and Technologies, Polydisciplinary Faculty, Sultan \\ Moulay Slimane University, Béni-Mellal, Morocco \\ ${ }^{4}$ Laboratory of Biology Engineering, Faculty of Sciences and Techniques, Sultan Moulay Slimane University, \\ Béni-Mellal, Morocco \\ ${ }^{5}$ Research Group of Landscapes Dynamic, Risks and Patrimony, Faculty of Letters and Human Sciences, Sultan \\ Moulay Slimane University, Béni-Mellal, Morocco \\ ${ }^{6}$ Institute of Geoecology and Geoinformation, Adam Mickiewicz University in Poznan, Poland
}

Manuscript received: December 3, 2017

Revised version: February 5, 2018

Bouzekraoui H., Barakat A., Elyoussi M., Touhami F., Mouaddine A., Hafid A., Zwoliński Zв. Mapping geosites as gateways to the geotourism management in Central High-Atlas (Morocco). Quaestiones Geographicae 37(1), Bogucki Wydawnictwo Naukowe, Poznań, pp. 87-102. 11 figs, 1 table.

Aвstract: Demnate commune and High-Tessaout valley are located in the Moroccan central High-Atlas. They have a great and much diversified geological and geomorphological heritage and exceptional landscapes of high mountains. The data obtained from the current work indicate that the studied area present high tourist vocation, in the fact that this territory preserves a large number of geosites linked to many witnesses fossils of extinct animals such dinosaurs footprints, outcropping rock formations of the Precambrian and Mesozoic. Further, it has many remarkable landforms and geosites such as canyons, natural bridge, spectacular waterfalls and scree slopes. The findings support that the area attracts many tourists every year. However, this number remains restricted due to the lack of tools of promotion and mediation of its geoheritage and also due to the low exploitation of the geodiversity. Regarding this situation, geotouristic routes represented on touristic map appear as an essential tool for geotourism promotion and as an efficient means of geosciences popularisation. This paper illustrates three geotouristic routes describing the main geosites in rural areas of Demnate and High-Tessaout valley. These geotourism itineraries can help to explain the high potential interest of the studied areas in geotourism terms.

KEY WORDS: geoheritage, geosites, geotouristic map, geotourism itinerary, Central High-Atlas

Corresponding author: Hicham Bouzekraoui, hbouzekraoui@gmail.com

\section{Introduction}

Morocco is endowed with abundant natural diversity that positions it well to compete in the regional, national and international tourism market. The natural diversity such as various landscapes including coastlines, beaches, extensive mountain, desert landforms, canyons and 
natural arch ranges. Nevertheless, there are several tourism niches including geological and geomorphological geodiversity (MTA 2009), which have a high potential for Moroccan tourism but do not been sufficiently recognized and unfortunately have not been appropriately employed in development planning so far. Recently, to diversify its tourism product Morocco has started using the diversity and richness of its natural (biotic and abiotic), cultural and landscape resources for the promotion of sustainable tourism (MTA 2009). Furthermore, geodiversity and geoheritage have recently begun to be studied (e.g. El Wartiti et al. 2009, Waele, Melis 2009, Tahiri et al. 2011, Erami et al. 2015, Bouzekraoui et al. 2017). However, many mountain regions, especially in central High-Atlas, require sustainable development and new means to increase the income of a population, mostly poor. Thus, focusing on its geotourism potential through its identification and valorisation, geosites can be the best hope and useful tool contributing to sustainable economic development of the regions.

The scientific community has been particularly active in the field of the popularization of geosites for about twenty years. Current initiative valuation of geosites has gained a significant and international audience (e.g. Perret 2014). Geoheritage and geotourism are intimately linked together in the fact that the development of the latter increase if the former is rich, diverse and scenic (Migon, Goudie 2012). In the same direction, there has been a growing interest in geoheritage and geosites to geotourism promotion. Geoheritage can be viewed as a considerable resource for geotourism and geo-educational activities (Kubalíková et al. 2017). Additionally, when the geoheritage is interpreted in a simple, an understandable way, it may become attractive for tourists (Górska-Zabielska, Zabielski 2017). Geotourism is a new form of tourism utilizing geological and geomorphological sites and landscapes (Thomas 2012), though Ollier (2012) believes that individual landform or geological formation are equally attractive geotouristically. It is of increasing importance for both local and regional economy and the management of the territory and its environment (e.g. Brocx, Semeniuk 2007, Dowling 2011, Žáček et al. 2017, Zwoliński et al. 2017). It also contributes to the identification, conservation and promotion of geoheritage
(Hose 2011, Farsani et al. 2014). Geotourism also provides jobs and new economic dynamics in regions, particularly in rural, where there is a severe shortage of other jobs (El Wartiti et al. 2009). The valorisation of local and regional geosites became, in the last three decades, a significant challenge that mobilized among others scientific community. The geosites defined as remarkable sites containing rocks, geological phenomena, or specific landforms need valorisation and protection (Nascimento et al. 2007).

Recently, mapping has gained a higher level of attention in geoheritage research (e.g. Regolini-Bissig, Reynard 2010, Fuertes-Gutiérrez, Fernández-Martínez 2012, Comănescu et al. 2013, Comănescu et al. 2017, Zwoliński et al. 2018). A map represents a link in a geosciences information exchange between the geotourism cartographer and their target public and the successful map must be interpreted without any additional help or information by the final user (FuertesGutiérrez, Fernández-Martínez 2012). In the context of geotourism, the main issue concerns the preparation of maps useful for tourists when they visit a geosite (Reynard 2005). Geoheritage and geosite mapping became more widespread (e.g. Ilieş et al. 2011, Fuertes-Gutiérrez, FernándezMartínez 2012, Zwoliński, Stachowiak 2012, Comànescu et al. 2013, Badang et al. 2016). The first geotouristic maps were established in Italy for the regions of Abruzzo, Parma and Emilia Romagna Castaldini et al. (2005), and these studies served as a basis for all the Italian country (Brandolini, Pelfini 2010), and in various countries of Europe (e.g. Zwoliński 2004, Ilieş et al. 2011, Fuertes-Gutiérrez, Fernández-Martínez 2012, Comănescu et al. 2013). In fact, there are five types of geotouristic maps (Regolini-Bissig 2010, 2012), which differ from each other by the amount of geoscientific and tourist information represented in the map. Generally, they target two audiences: (a) geoscience specialists for which the amount of geoscientific information overcomes (the two types of geoscientific maps); (b) the general public of non-specialists for which the tourist character prevails (both of Index and Touristic maps). The interpretive map corresponding to the fifth category is covering the two above audiences. Geotourism maps appear recently as an excellent tool applied to geosite promotion and management (Reynard 2008, Smith 
et al. 2011). They offer and provide geotourists more information on geosites and itineraries, making visits much easier (Coratza et al. 2008). In this paper, we provide an example of a geotourism map dedicated to geotourism promotion in Mountain areas from Demnate to High-Tessaout valley within Moroccan central High-Atlas.

\section{Study area}

The study area of Demnate and HighTessaout valley is located in the heart of the central High-Atlas in the centre of Morocco (Fig. 1). Administratively, it is part of Azilal and Ouarzazate provinces, and it is on the regional road connecting Demnate to Skoura. It lies between $31^{\circ} 15^{\prime} 00^{\prime \prime}-31^{\circ} 35^{\prime} 00^{\prime \prime} \mathrm{N}$ and $6^{\circ} 30^{\prime} 00^{\prime \prime}$ $7^{\circ} 00^{\prime} 00^{\prime \prime} \mathrm{W}$. This study area is part of the Geopark M'goun that is given the label by Global Network of National Geoparks (GGN) developed under the auspices of UNESCO, during the $6^{\text {th }}$ World Conference on Geoparks in Canada in September
22 , 2014. Demnate is located roughly $110 \mathrm{~km}$ east of Marrakech. It is one of the oldest cities in Morocco as it is used to be a linking point between the Moroccan south and Marrakech. Its construction goes back to the year 998, forty years before Marrakech. Geoheritage elements in Demnate and High-Tessaout valley territory are numerous. The Demnate commune contains one of the most remarkable geosites within central High-Atlas. The High-Tessaout valley is one of the most beautiful and much-appreciated valleys within central High-Atlas and one of the most attractive in Morocco. It is located at a few kilometres to the northeast of the highest mountains peaks of the central High-Atlas such as $\mathrm{M}^{\prime}$ goun (4 $066 \mathrm{~m}$ a.s.l.) and Jbel Rat Mountain (3 $800 \mathrm{~m}$ a.s.l.) and about $80 \mathrm{~km}$ east of Demnate city. Tessaout means the planer in Berber due to the extraordinary erosion power of Tessaout River. However, it is a hidden valley despite its tourism potential, cultural heritage and its geodiversity which dates back to the Precambrian and is essential for understanding the history

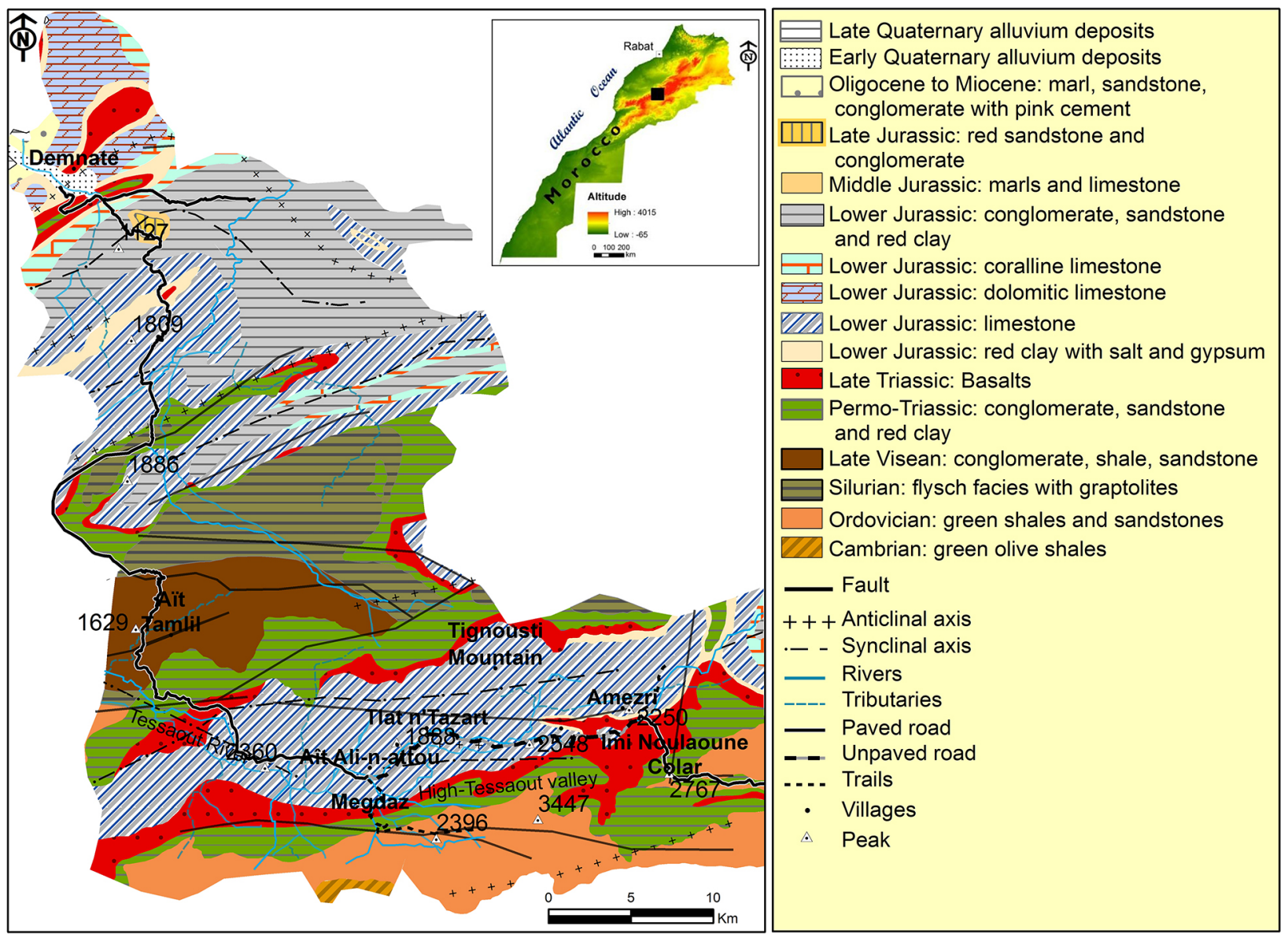

Fig. 1. Geographical location and geological map of the study area (acc. to Roch 1941). 
of central High-Atlas. The climate of the area is Mountainous-Mediterranean with wet and cold winters and heavy snowfalls followed by dry and hot summers (HCWCD 2010). The snowfall period is from December to February, and the snow cover can reach more than $60 \mathrm{~cm}$. According to the pluviothermic quotient of Emberger, the climate of the study area is semi-arid, with fresh winters in Demnate and cold winters in HighTessaout valley (Bouzekraoui et al. 2016).

\section{Geological setting}

In the area of Demnate and High-Tessaout valley the outcrops of Palaeozoic rocks end and the High-Atlas limestone begins. It can be a key region for analysing the deformations and relations Palaeozoic basement rock/Mesozoic sedimentary cover. The major rock formations outcropping in the study area are represented in map of Figure 1 extracted from the geological map of Morocco 1:200 000, sheet of DemnateTélouet (Roch 1941), and described in e.g. Tricart et al. (1972), Jenny et al. (1981), Biron (1982), Jenny, Couvreur (1988) and Michard et al. (2008).

The Palaeozoic basement, deformed during the Variscan orogeny, emerges from the surrounding Mesozoic sedimentary rock layers. It is constituted from base to top by Green olive shales of Cambrian, green shales and sandstone of Ordovician, flyshs with graptolith of Silurian and conglomerate, shales and sandstone of Late visean.

The Mesozoic geological formations overlying the Palaeozoic basement, are from bottom to top: Conglomerate, sandstone and red clay of Permo-Triassic, basalts of Late Triassic, red clay with gypsum and salts, Limestone, DolomiticLimestone Coralline Limestone and Marls, sandstone and red conglomerate of Lower Jurassic, marls and Limestone of Middle Jurassic, and red sandstone and conglomerate of Late Jurassic.

The Cenozoic covering the Mesozoic formations, is composed of sandstone and conglomerate with pink cement of the Oligocene to Miocene.

\section{Geomorphological setting}

Geomorphology of the study area is the result of various factors and morphogenetic processes, namely structural, karstic, periglacial and nival that have shaped the landscape through time. The geomorphological map of the study area is realized from the geological map of Morocco

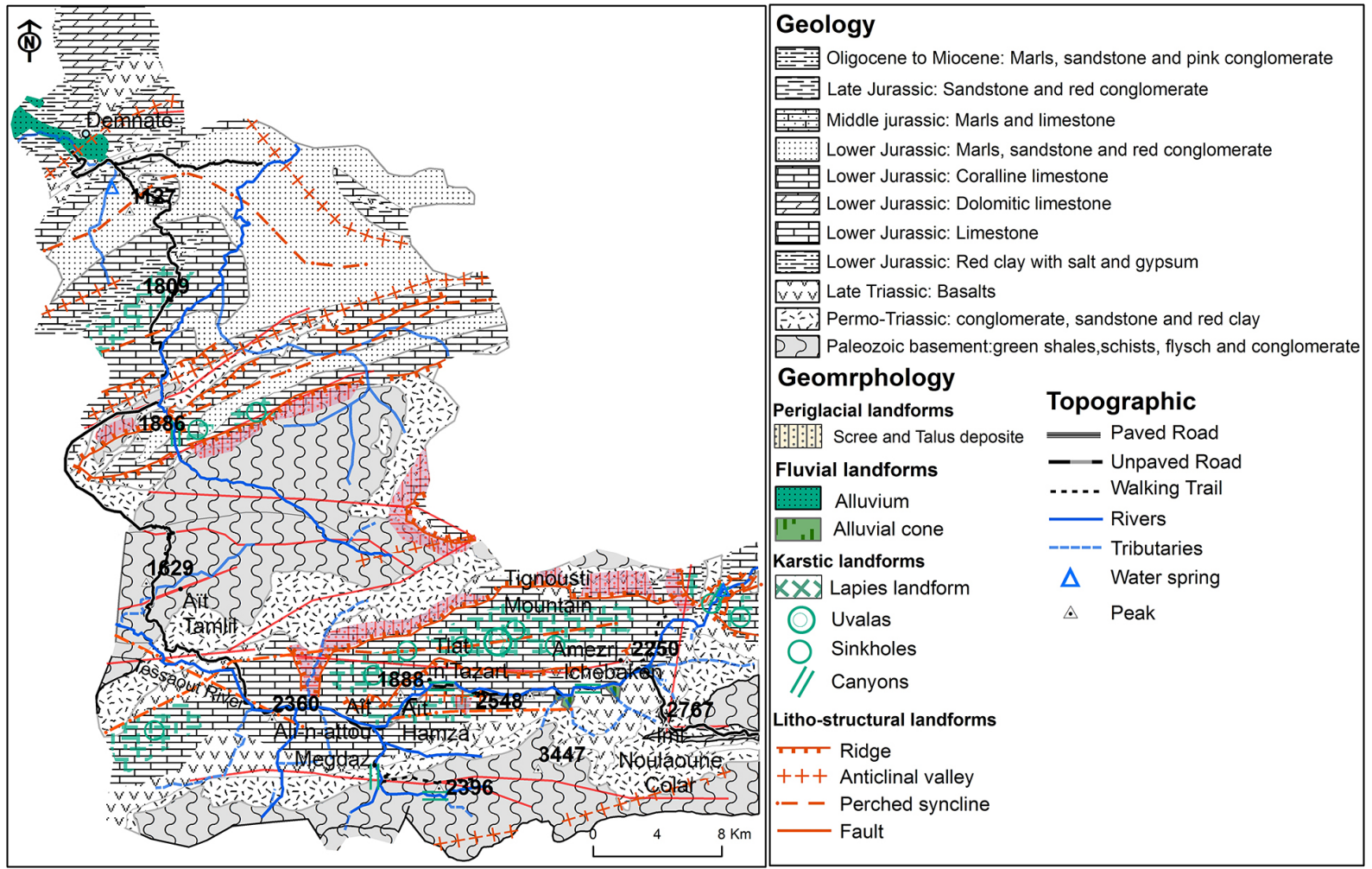

Fig. 2. Geomorphological map of the study area. 


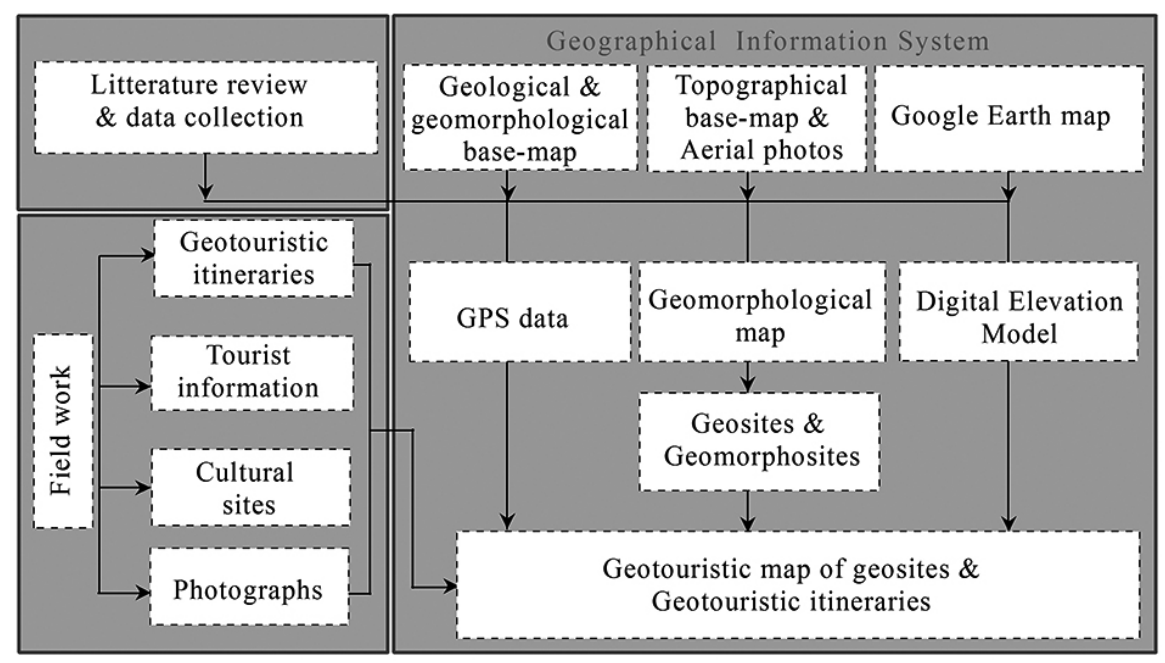

Fig. 3. Flow chart of used methodology.

1:200 000 sheet of Demnate-Télouet and geomorphological maps of Couvreur (1988) (Fig. 2). The geomorphological landforms of the study area are described below.

Litho-structural landforms: The main landforms of the central High-Atlas are created by alpine tectonics that folded sedimentary sequences, generating large synclines and anticlines with SW-NE direction. The anticline hinges have been eroded due to their high altitude and the thinness of the Upper Jurassic deposits. This led an inverted relief which is made by perched valleys in the Lower Jurassic limestone and sometimes by deep valleys cut into the Paleozoic rocks.

Karstic landforms occupy a significant area in the central High Atlas. The carbonate formations have been subjected to chemical weathering, which created dispersed or grouped karst landforms. Two types are observed; namely, the Quaternary lapies, swallow holes and sinkholes having decametric size, and the kilometer-scale uvalas and poljes that are older.

Periglacial landforms: The evolution of the high Atlas has involved, since the Plio-Villafranchian, periglacial processes responsible for the formation of gelifracts (cryoclastic debris) whose accumulation has led to the formation of scree cones and scree slopes. The latter occurs at the base of steep slopes built of Triassic to Lower Jurassic carbonate rocks. The freeze-thaw activity is responsible of solifluction that is marked by the formation of gradual mass of marls and clays wasting slope.

Nival landforms are formed by rock fragments resulting of physical rock disintegration and veiling the slopes and by reshaped talus deposits.

\section{Materials and methods}

The approach used in this work is based on personal research as well as works conducted by other researchers (e.g. Zwoliński 2004, Coratza et al. 2008, Regolini-Bissig, Reynard 2010, Ilieş et al. 2011, Fuertes-Gutiérrez, Fernández-Martínez 2012, Comànescu et al. 2013). The geotouristic map of the Demnate City and High-Tessaout valley borrows from previously published methodologies as mentioned above, combined to develop a new map that uses the best of each one of them. The text below clarifies how the geotouristic map of geosites and itineraries in Demnate and High-Tessaout valley was produced. Three steps were involved (Fig. 3):

1. The geological, geomorphological and touristic data were collected from the literature.

2. The literature data were complemented by the data gathered from fieldwork. Fieldwork observations were carried out. In this second step, the geosites were identified and classified according to the typology proposed by Grandgirard (1999). The geoscientific importance of geosites is determined by assigning them scientific and additional values according to Reynard et al. (2015). The geotouristic itineraries and geo-hiking trails connecting the most notable geosites with recommended stops have been proposed. Other tourist attractions such as scenic views of high mountain landscapes and material cultural heritage, as well as information about on-site accommodation and restaurants were also inventoried. 
3. The data collected were prepared in a GIS environment to generate the geomorphological and geotouristic map. The geomorphological map was used to identify landforms assessed as geosites (Fig. 2). This map is enriched with common indications for tourists such as geotouristic itineraries and historical monuments. Furthermore, Zwoliński (2004), Coratza (2008), Erhartič (2010), Regolini-Bissig and Reynard (2010) and Comànescu et al. (2013) have stated that the geotouristic map legend consists of two distinct categories. In the Demnate and High-Tessaout valley the geotouristic map we added a third category taking into account the broad definition of geotourism suggested by Rodrigues et al. (2011).

The first category includes symbols representing the main geological and geomorphological features; in our case, we used colours to describe the geology this region and symbols for the geomorphological features, and simple symbols for indicating the location of geosites. In this case, we also used coloured circles to designate the geomorphological processes responsible for the geosites of the area. They were established intending to reveal the geological and geomorphological heritage of the area and are indispensable for the understanding and learning the geological history of the High-Atlas.

The second category is dedicated to conventional symbols concerning touristic information and different types of geotourism itineraries. The proposed geotouristic itineraries are three examples of the great geotouristic potential of the Demnate city and Tessaout valley. They were established to reveal the geological and geomorphological heritage of the area.

The third category shows conventional symbols concerning cultural sites. For instance, the map is upgraded by different categories and quality of geotouristic itineraries and trails.

Moreover, most of the produced maps used as base map a topographic, geological map satellite orthophotomaps or digital elevation model (DEM). In the geotouristic map of Demnate and High Tessaout-valley, a digital elevation model of Google-Earth was used to obtain re- lief shading maps to visualize the topography. Photographs with simple geomorphological descriptions of the most attractive geosites are reported in the map margins.

\section{Geoheritage mapping approach}

In the last two decades, several authors have proposed approaches to establish specific geoheritage maps, i.e. Regolini-Bissig (2010) and Comănescu et al. (2013) for interpretative maps, Erhartic (2010) for conserving geoheritage map, Ilieş et al. (2011) for geoheritage map, Coratza et al. (2008) for geo-hiking map, Serrano and Gonzales Trueba (2011) for environmental education and landscape leisure, Fuertes-Gutiérrez and Fernández-Martínez (2012) for geosites maps and Zwoliński (2009) for geodiversity maps. From our perspective, it is the interpretative map that is most relevant for promoting geotourism in the Demnate and High-Tessaout valley, in the fact that it presenting a balanced proportion between scientific and touristic information. It is used to communicate geoscientific themes with non-specialist public to provide the opportunity to understand geomorphological or geological phenomena, formations or evolution. Tourist information is of secondary importance as mentioned by Rodrigue et al. (2011). The map is derived from the appropriate simplifications of the geomorphological map. It combines the most evident geological and geomorphological natural and anthropic features which can be observed and recognized even by non-experts and touristic information as suggested by Erhartič (2011).

\section{Results and Discussion}

\section{Most remarkable geosites of the Demnate City and High-Tessaout valley}

In the analyzed area, 27 geosites have been documented and have geoscientific significance, and only few of them are well preserved. These sites have formed the basis of geoheritage elements inventory. The information of these geosites are taken from work field and literature (Couvreur 1988, Jenny, Couvreur 1988, Mombarron, Mombarron 2015) (Table 1). They come from five different morphogenetic agents 
Table 1. Most remarkable geosites of the area according to their location, lithology and typology.

\begin{tabular}{|c|c|c|c|c|c|}
\hline No. & Geosites & Commune & Lithology & $\begin{array}{l}\text { Typo- } \\
\text { logy }\end{array}$ & $\begin{array}{l}\text { Belonging to } \\
\text { the M'goun } \\
\text { Geopark }\end{array}$ \\
\hline \multicolumn{6}{|c|}{ Geomorphological geosites 'Geomorphosites' } \\
\hline 1 & Waterfall of Asfdar & Ait Tamlil & Limestone & Line & No \\
\hline 2 & $\begin{array}{l}\text { Springs and waterfall of Tlat-n-Tazart (Guig- } \\
\text { mi) }\end{array}$ & Aït Tamlil & Limestone & Site & No \\
\hline 3 & Springs and waterfall of Imi- $n$-Ifri & Demnate & Limestone & Site & Yes \\
\hline 4 & Springs and waterfall of $\mathrm{M}^{\prime}$ goun & Imi Nouloune & Limestone & Site & No \\
\hline 5 & Canyons of Almsa & Tifni & Limestone & Line & No \\
\hline 6 & Canyons of Ichbaken & Imi Nouloune & Limestone & Line & No \\
\hline 7 & Canyons of Megdaz & Aït Tamlil & Limestone & Line & No \\
\hline 8 & Canyons of High-Tessaout & Imi Nouloune & Limestone & Line & Yes \\
\hline 9 & Canyons of Asfdar & Imi Nouloune & Limestone & Line & No \\
\hline 10 & Scree cone of Tlat-n-Tazart & Aït Tamlil & Limestone & Area & No \\
\hline 11 & Alluvial fan of Ichebaken & Imi Nouloune & Limestone & Area & No \\
\hline 12 & Alluvial fan of Amezri & Imi Nouloune & Limestone & Area & No \\
\hline 13 & Scree slopes of Amezri & Imi Nouloune & Limestone & Area & No \\
\hline 14 & Natural bridge of Imi-n-Ifri & Demnate & Limestone & Site & Yes \\
\hline 15 & Landslide of Amezri & Imi Nouloune & Red Clay & Area & No \\
\hline 16 & Fairy chimneys of Talat-n-Tazart & Aït Tamlil & Red Clay + Limestone & Site & No \\
\hline \multicolumn{6}{|c|}{ Igneous and volcanic geosites } \\
\hline 17 & Basaltic lava flow of Ait Aadel formation & Aït Tamlil & Basalts & Area & No \\
\hline \multicolumn{6}{|c|}{ Paleontological geosites } \\
\hline 18 & $\begin{array}{l}\text { Footprints of unknown mammalian of Meg- } \\
\text { daz }\end{array}$ & Aït Tamlil & Limestone & Area & Yes \\
\hline 19 & $\begin{array}{l}\text { Footprints of herbivorous dinosaurs of } \\
\text { Iouariden }\end{array}$ & Sidi Boulkhalf & Siltstones + Red Clay & Site & Yes \\
\hline 20 & $\begin{array}{l}\text { Footprints and moving tracks of carnivorous } \\
\text { dinosaurs of Iouaridene }\end{array}$ & Sidi Boulkhalf & Siltstones + Red Clay & Site & Yes \\
\hline \multicolumn{6}{|c|}{ Sedimentological geosites } \\
\hline 21 & Ripple marks in Iouariden & Sidi Boulkhalf & Sandstone & Area & No \\
\hline 22 & Inverted cross-bedded sandstone & Aït Tamlil & Sandstone & Site & No \\
\hline 23 & Sedimentary structure in teepee & Aït Tamlil & Limestone & Site & No \\
\hline 24 & Desiccation cracks (Mudcrack) & Sidi Boulkhalf & Limestone & Area & No \\
\hline \multicolumn{6}{|c|}{ Stratigraphic and structural geosites } \\
\hline 25 & $\begin{array}{l}\text { Angular unconformity between the Precam- } \\
\text { brian (PIII) and the Paleozoic (Cambro-Ordo- } \\
\text { vician) }\end{array}$ & Megdaz & $\begin{array}{l}\text { Rhyolite, quartzite + } \\
\text { Sandstone }\end{array}$ & Site & No \\
\hline 26 & $\begin{array}{l}\text { Angular unconformity between the Palaeozo- } \\
\text { ic (Cambrian-Ordovician metamorphic rocks) } \\
\text { and the secondary (Triassic sedimentary } \\
\text { rocks) of Almsa }\end{array}$ & Aït Tamlil & $\begin{array}{l}\text { Shale, sandstone + } \\
\quad \text { Limestone }\end{array}$ & Point & No \\
\hline 27 & Normal and reverse faults & Aït Tamlil & Limestone & Point & No \\
\hline
\end{tabular}

that reflect the geodiversity of this mountain area, including sixteen geomorphological geosites or geomorphosites, four sedimentological geosites, three paleontological geosites, one igneous and volcanic geosites, and three stratigraphic and structural geosites. Further, six of all geosites belong to M'goun Geopark. All these sites are summarized in Table 1. From an educational point of view, these geosites are valuable examples of the evolution of central High-Atlas. They have been selected by taking into account some fundamental features such as geological relevance, good quality of the exposure and easy access, based on their scientific value, representativeness, high aesthetic value, rarity and potential for both education and tourism. 


\section{Geotouristic map of the Demnate City and High-Tessaout valley}

The geotouristic map produced in this study indicate three geotouristic itineraries connecting the most 27 spectacular geosites and high mountain landscapes of Demnate and High-Tessaout valley in Moroccan central High-Atlas (Fig. 4). This geoheritage and geosites represents the background of the three proposed geotourism itineraries as mentioned by Rodrigues et al. (2011). Therefore, tourist information is added to facilitate the visit of the most remarkable geosites and contains information about tourist offices, access,

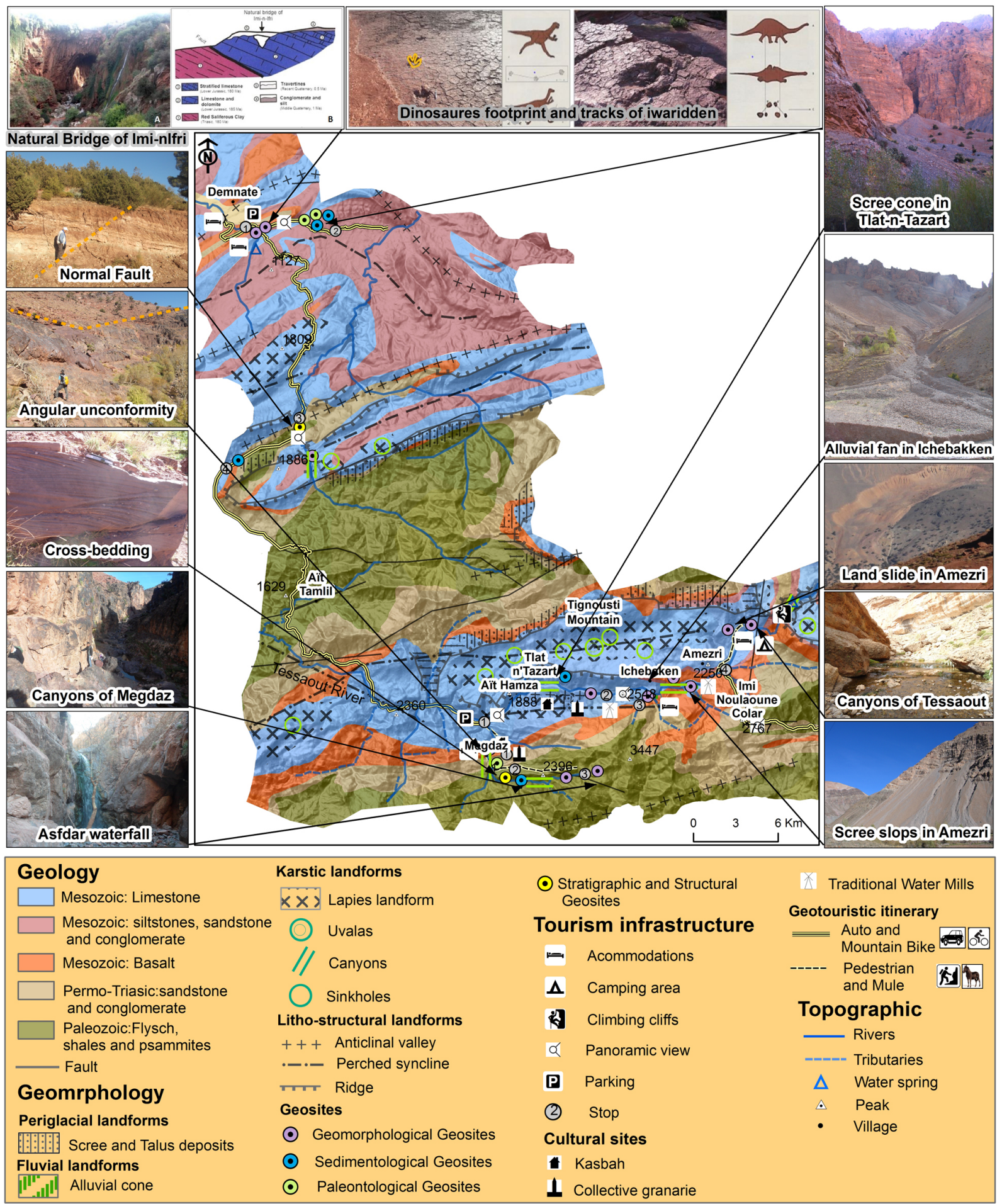

Fig. 4. Geotouristic map of the Demnate and High-Tessaout valley. 
accommodation facilities, leisure areas, belvedere points, viewpoints. Finally, cultural sites such as the main historical and cultural monuments are added to increase the attractiveness of the visited regions as revealed in his broad definition of geotourism (Rodrigues et al. 2011). This is justified because the analyzed area is famous and much-visited thanks to its beauty and cultural legacy that includes traditional water mills, fortified home (Kasbah) and old collectives granaries that were built by the indigenous Berber tribes.

\section{Description of the geotouristic routes and geo-hiking trails}

The proposed geotouristic itineraries connect a succession of impressive outcrops distributed between the western part and the centre of central High-Atlas whose age ranges from Precambrian (PII) to Holocene. Furthermore, it offers the opportunity to visit some of the most interesting and best exposed geosites. Each itinerary has been conceived in such a way as to illustrate the geological and geomorphological evolution of this mountain. The geotouristic itineraries and trails proposed are approximately $160 \mathrm{~km}$ in length and can be completed in 3 days, one day each. These geotouristic routes can be reached out by car, bike, mule or geo-hiking.

$1^{\text {st }}$ Geotouristic itinerary: From Demnate city to Megdaz village, there is an option that combines traveling by car or biking. Taking this route tourists can pass, in one day, the most stunning geosites of central High-Atlas. The starting point is located in Demnate city centre. This itinerary includes the important historical monuments such as the Kasbah and the town walls with its gateway. Furthermore, the area entails Bougrarte potters, as well as the palace of the sons of King Ismail.

\section{Stop 1 on the natural bridge of Imi-n-Ifri}

This stop is dedicated to the natural bridge of Imi-n-Ifri (Fig. 5), which is the most remarkable geosite of the area. It is located $6 \mathrm{~km}$ northeast of the centre of Demnate at about 1000 m a.s.l. Tourists do not have to veer far off the paved road leading to Iouaridene to see the natural bridge. The Tissilt River drains the waters of the large Tisgui syncline located to the southeast of the site. This river has sliced for thousands of years the thick rock bar of gray limestones and dolomite of the Imi-n-Ifri formation of Lower Jurassic (Sinemurian-Pliensbachian). Much later, during the Pliocene, the freshwater springs emerged from the aquifer through both its banks. The spring water charged with dissolved carbonates that may be precipitated as open-air deposit, had gradually built masses of travertine deposits forming a natural rock bridge over a gorge (Monbaron, Monbaron 2015). Under this natural bridge, following a path through the travertines, we can admire the concretions and stalactites taking various forms, while we can also admire against the light from the gorge that looked like a map of Africa. This geo-monument is very fragile; the most prominent danger is due to the heavy traffic which transits on the bridge.
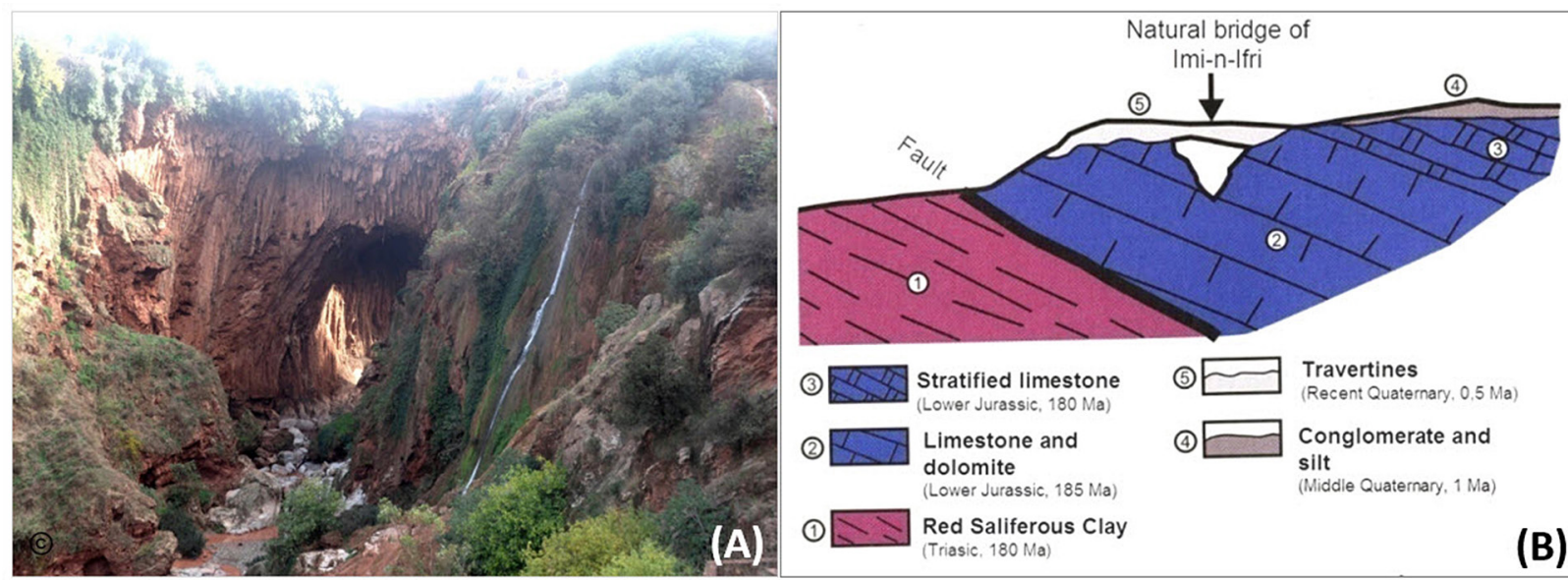

Fig. 5. The geosite of Imi-n-Ifri natural bridge.

A) photograph of the bridge, B) its geological cross-section according to Monbaron and Monbaron (2015). 


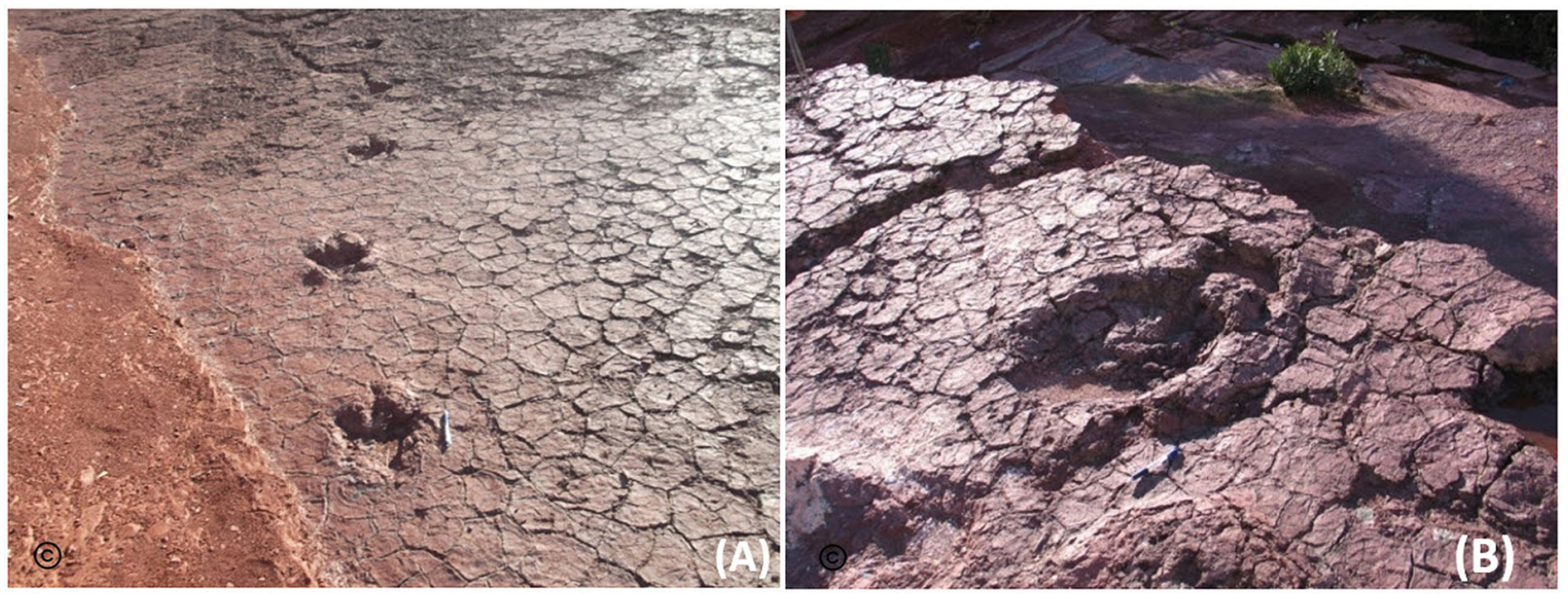

Fig. 6. The geosites of dinosaur footprints and tracks of Aït Iouaridene.

A) footprints and tracks of carnivores Theropods Two-Legged, B) footprints Herbivorous Quadrupedal Sauropod.

Stop 2 in the dinosaur footprints and tracks of Ait Iouaridene geosites

This stop is linked to one of the most famous geosites within central High Atlas and the Geopark M'goun. The dinosaur footprints and tracks of Iouaridene geosite are located 10 $\mathrm{km} \mathrm{NE}$ of the city of Demnate; the site is indicated by an information panel. They represent traces of the dinosaurs that inhabited these areas during the period from the Lower Jurassic to the Lower Cretaceous between $180 \mathrm{Ma}$ and 80 $\mathrm{Ma}$. This site shows more than a dozen of footprints and two tracks of agile Theropods (Fig. 6A) as well as heavy Sauropods (Fig. 6B). The dinosaur footprints and tracks of Aït Iouaridene constitute scientific heritage of worldwide importance. They are printed on tilted layers of siltstones of the Iouaridene Formation (165 Ma).
This siltstone showed desiccation cracks and sedimentary structures of bidirectional ripple marks. All above paleontological and sedimentological features are characteristics of the shallow lagoon depositional environment with hot and humid climate (Monbaron, Monbaron 2015).

\section{Stop 3 in Ighil Oubni Village}

In this stop, a normal fault of direction N70 called the Atlas direction appears clearly (Fig. 7A). It affects stratified limestones of Jbel Rat Rock Formation. These limestone layers also present a distinctive tepee sedimentary structures (Fig. 7B) consisting of a fold that resembles an inverted depressed $\mathrm{V}$ in cross section. These sedimentary structures are the result of sedimentation in a basin with evaporates such as gypsum and salt.
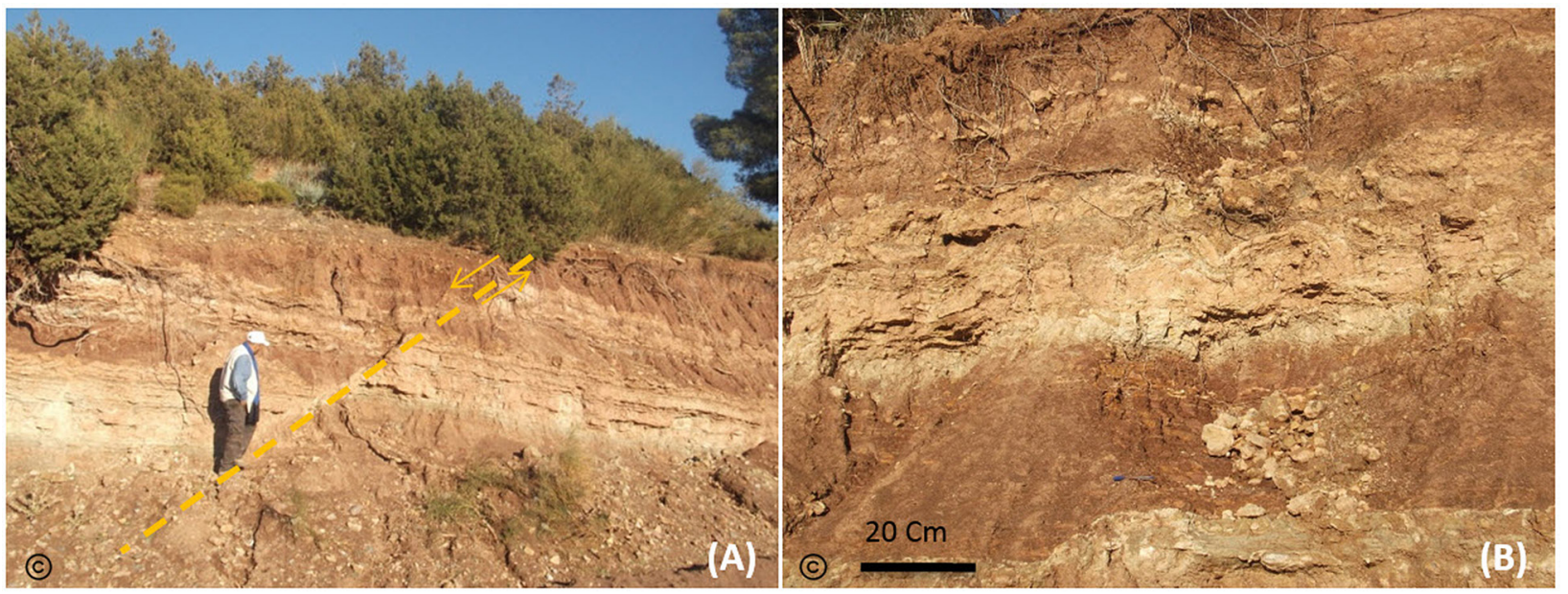

Fig. 7. A) Normal Fault of direction N70, B) Tepee sedimentary structures in limestone. 
This stop is located $19 \mathrm{~km}$ from the natural bridge, at the bottom of the river canyon within the Til Mountain. The canyon is the result of constant erosion of the limestone of the Lower and Middle Jurassic by the Asif-n-Ghasf River. The Asif-n-Ghasf River flows into the canyon from the southeast to the northwest between 1 $640 \mathrm{~m}$ and $1498 \mathrm{~m}$ a.s.l., over a length of about $3 \mathrm{~km}$. The water pressure of the river cut deep into the syncline of Til generating a steep slope of approximately $350 \mathrm{~m}$ high. Scree covers these slopes; the rock fragments came from the overlying limestone cliffs. The Til Mountain is that of a perched syncline folded during the Alpine orogeny. The syncline shows northeast-southwest axial direction. It consists of the Lower Jurassic limestone resting on red siltstones, sandstone, and basalt of the Late Triassic age (Couvreur 1988).

\section{Stop 4 in Talmsa Village and Til syncline}

In this stop, the route leaves the Triassic sedimentary cover and passes above the Palaeozoic basement having a total area of $400 \mathrm{~km}^{2}$. The Paleozoic basement correspond to the imbricate thrust sheets developed under the influence of the Variscan orogeny. The Lower Jurassic carbonates overlay the Triassic sandstones, siltstone, and basalt. The horizontally parallel strata of sedimentary Triassic rock overlay the Paleozoic thrust sheets by angular unconformity which are gaps in the geologic record that may indicate episodes of crustal deformation especially during central High-Atlas orogeny. The Til Mountain is a perched syncline of the Lower Jurassic limestone that overlays the Triassic rocks and Palaeozoic bedrock and has some stunning cliff. This stop represents a key area for the study of the relations between the Mesozoic sedimentary cover and the Palaeozoic basement and the High-Atlas orogeny (Monbaron, Monbaron 2015).

$2^{\text {nd }}$ Geotouristic itinerary: The second itinerary is a one-day trip. It serves as a link between Megdaz village and the waterfall of Megdaz. This itinerary may just be one of the best geo-hiking trails in this area, traveling by mule is an option.

\section{Stop 1}

The proposed itinerary has been established due to a desire to present the peculiarities of this area. This stop is one hour's walk along the trail and leads to a type of sedimentary structure of cross-stratification in Triassic sandstones (Fig. $8 \mathrm{~A})$, which consists of sets of laminae that are inclined to the main horizontal bedding planes. These sedimentary structures are not common because they require the current to be equal in both directions, which rarely happens in nature. The time represented by each cross-stratified layer is likely to be many years (Nichols 2009). On the same sandstone rocks of the Triassic age, there is a rock engraving in the shape of a semicircle. This rock engraving is explained by the nomadic shepherds as a copy of the original rock encountered in this region. On this stop, tourist will also see a limestone rock block of Lower Jurassic detached from the above carbonates, on which ten footprints and one track of the paws derived from unknown wild mammal animals are present (Fig. 8B).

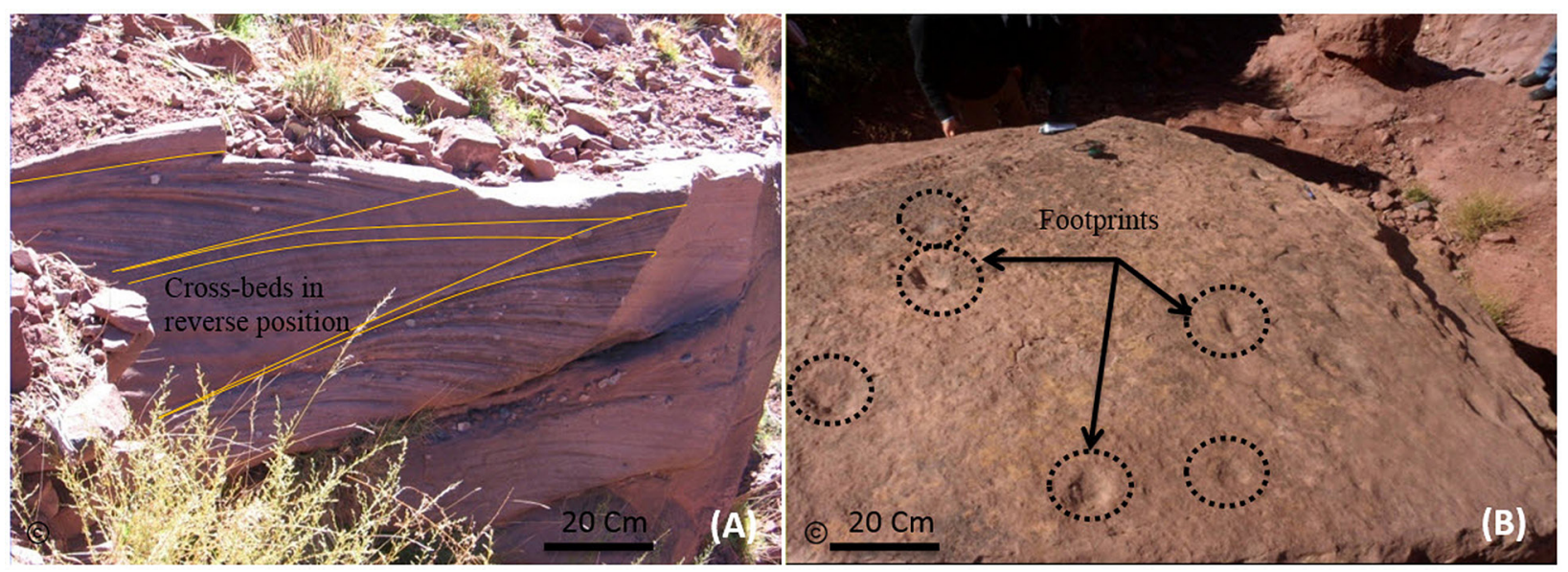

Fig. 8. A) Sedimentary structure of cross-stratification, B) footprints and two tracks of unknown wild mammalian. 

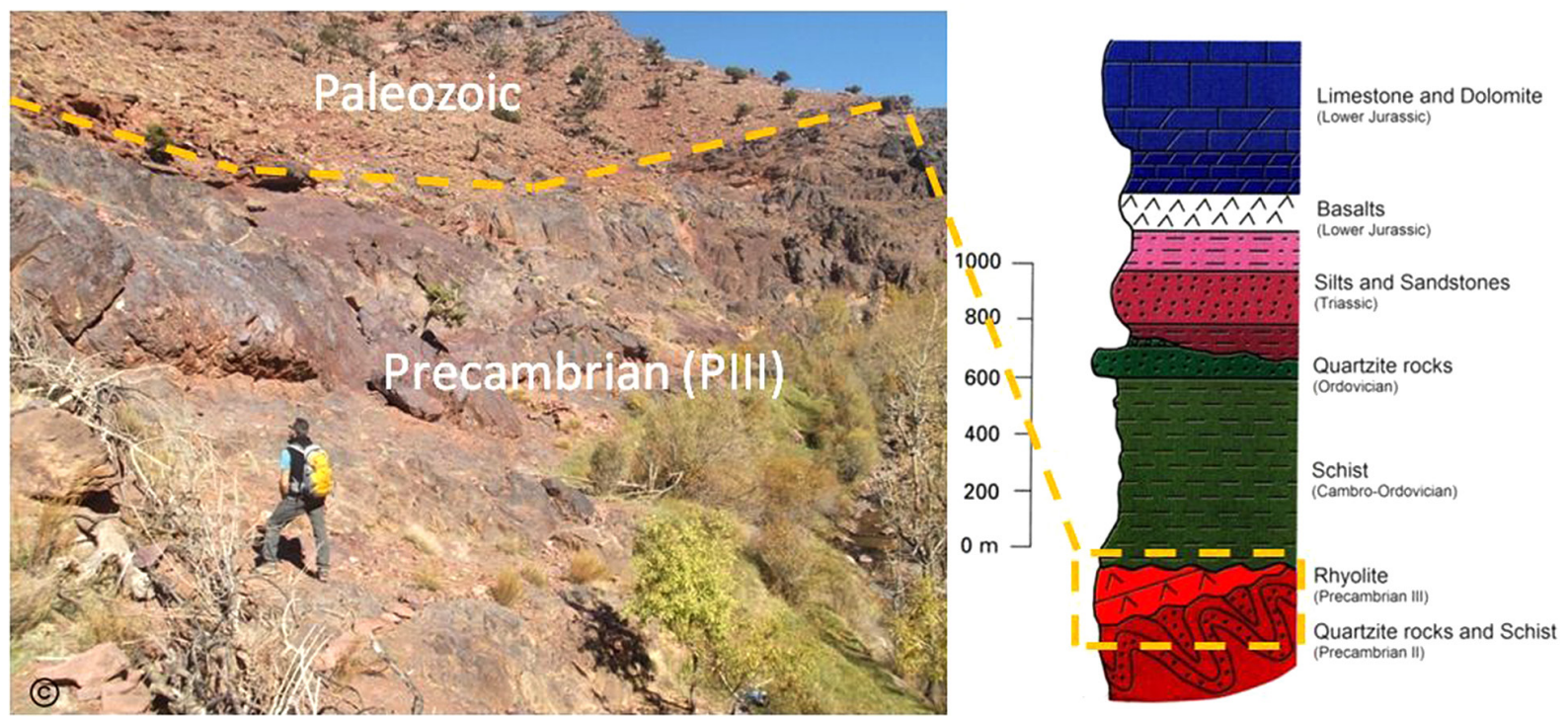

Fig. 9. Angular unconformity between the Paleozoic and Precambrian (PIII) with its stratigraphic column according to Monbaron and Monbaron (2015).
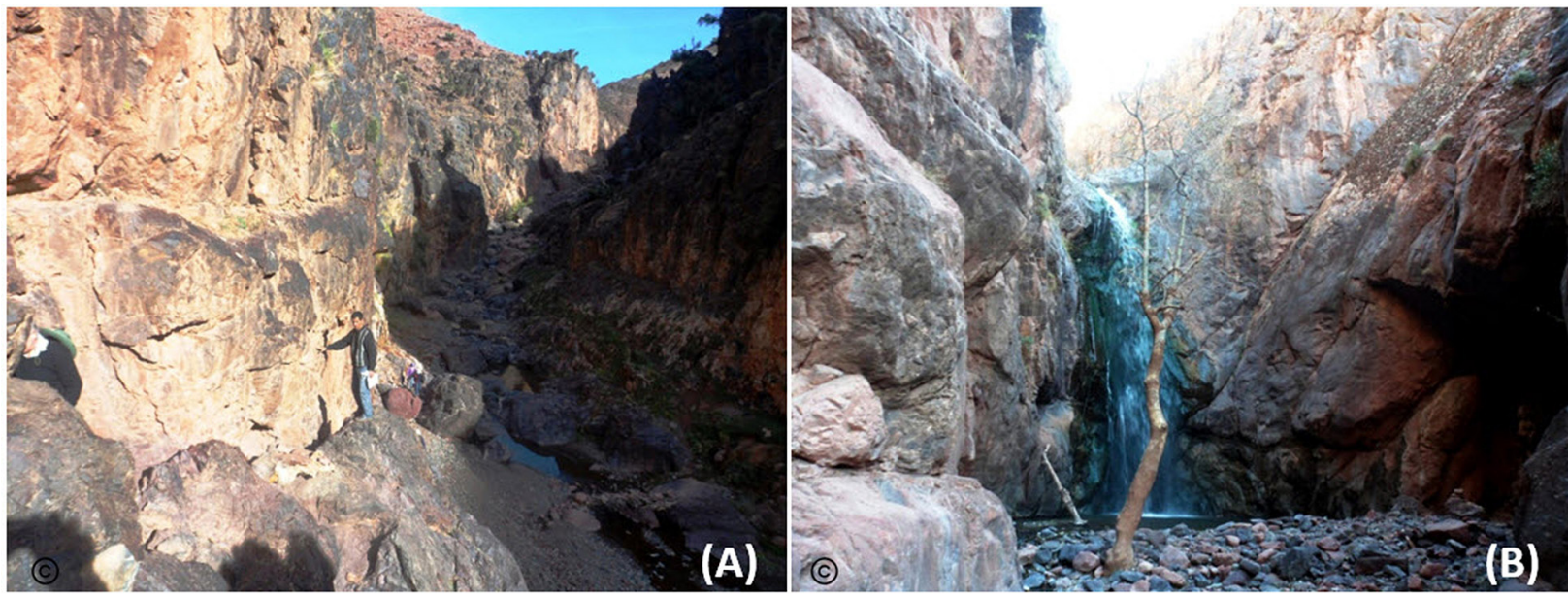

Fig. 10. Canyon of Megdaz, B) Asfdar waterfall.

\section{Stop 2}

This stop is proposed to see the most important geodidactic angular unconformity in central HighAtlas (Fig. 9). This major angular unconformity of Megdaz is between the rocks of Palaeozoic and Precambrian age. The Palaeozoic inlier is a thick series of schists and quartzites of the CambroOrdovician of Ait Tamlil formation which is separated by angular unconformity from rhyolite of the Precambrian (PIII) and quartzites and schists of Precambrian (PII) (Jenny, Couvreur 1988).

\section{Stop 3 in Megdaz canyon and Asfdar waterfall}

The last stop of this trail concerns the most remarkable canyon (Fig. 10A) and waterfall (Fig. 10B) in the area. The canyon of Megdaz has a length of about a dozen kilometres and a depth of approximately $100 \mathrm{~m}$ in some places. The most important feature of this geosite is the genetic type of rock in which the canyon has developed. In many cases in central High-Atlas and the world, deep narrow canyons are developed in carbonates, limestone and dolomites. In this case, these are metamorphic rocks, namely schists, psammite and quartzites. The canyon is originated through a combination of tectonic features and long periods of fluvial erosion. This is because the direction of this canyon follows a fault zone. The waterfall of Asfdar is developed in the hidden canyons of Megdaz. It is the result of a vertical slope break of a height more than $15 \mathrm{~m}$ in the watercourse of Megdaz River. Huge bare cliffs border the waterfall have been carved in the Palaeozoic basement rocks (Couvreur 1988). 
$3^{\text {rd }}$ Geotouristic itinerary: From Ait Ali-nAttou in the east to High-Tessaout canyons in the west, passing through Ichebaken and Amezri, the most beautiful villages of the High-Tessaout valley are present. This itinerary is running along the bed of the Tessaout River, mostly between two vertiginous cliffs of several hundred meters high. The river shaped its canyon in the Lower Jurassic limestone.

\section{Stop 1 in Tlat- $\mathrm{n}$-Tazart Village}

This village is located at Azilal and Ouarzazate provinces border. It was chosen as a stop because it contains remarkable landforms: alluvial fans and scree cones at the foot of outstanding cliffs, Fairy chimneys or earth pyramide, water spring forming waterfall.

1. The water spring of Tlat-n-Tazart is karstic water spring. Its water comes from the base of carbonates of the Lower and Middle Jurassic (Couvreur 1988). It forms a spectacular waterfall about $30 \mathrm{~m}$ high on the Tignousti Mountain slop in the right side of Tessaout River.

2. Fairy chimneys of Tlat-n-Tazart: this landscape is the result of slope erosion leading to the steepening of valley sides. The evolution of this landscape starts with gentle slopes, which are later differentially eroded due to the variable resistance to fluvial erosion of different rocks of Tessaout valley. Channel erosion in less resistant red Triassic siltstones has cleared more resistant limestone blocks, which detached from the overlying limestone cliffs; these blocks overcome the chimneys of the fairy chimneys (Fig. 11A) (Couvreur 1988).
3. Scree cones are abundant in High-Tessaout valley on the slopes built of the Triassic red sandstones. These screes cones have been formed by accumulation of coarse rock fragments detached from the overlying limestone cliffs (Fig. 11B). These fragments are prepared by freeze-thaw weathering and are then displaced by gravity (Couvreur 1988). They have taken the form of cones because they come from a feeder channel concentrating their path downwards. These screes cones are entrenched by the Tessaout River.

\section{Stop 2 in Ichebakken Village}

1. Alluvial fan in Ichebakken (Fig. 11C) which is fed by floods and debris flows. Gravels originate from the carbonate cliffs of the Lower Jurassic age, they are the result of fragmentation by frost weathering. The main characteristic of all High-Tessaout valley alluvial fans is that tourists can see the debris flows source area and the feeder channel (Couvreur 1988).

2. Ichebakken canyon is a deep narrow valley with steep to vertical walls resulting from the erosive activity of a Tessaout river in the Cenozoic. The Tessaout River flows in Ichebaken from east to west between Tignousti and Azghif synclines, from $2212 \mathrm{~m}$ in $1985 \mathrm{~m}$ a.s.l., over a length of $8 \mathrm{~km}$. The depth of this canyon in general about $300 \mathrm{~m}$ but in some sites, it exceeds $700 \mathrm{~m}$ (Couvreur 1988). The steep sides of the canyon are different lithology, in the fact that the fault which guided the river follows a zone of facies change. The slope of the right bank is crowned with continuous cliffs

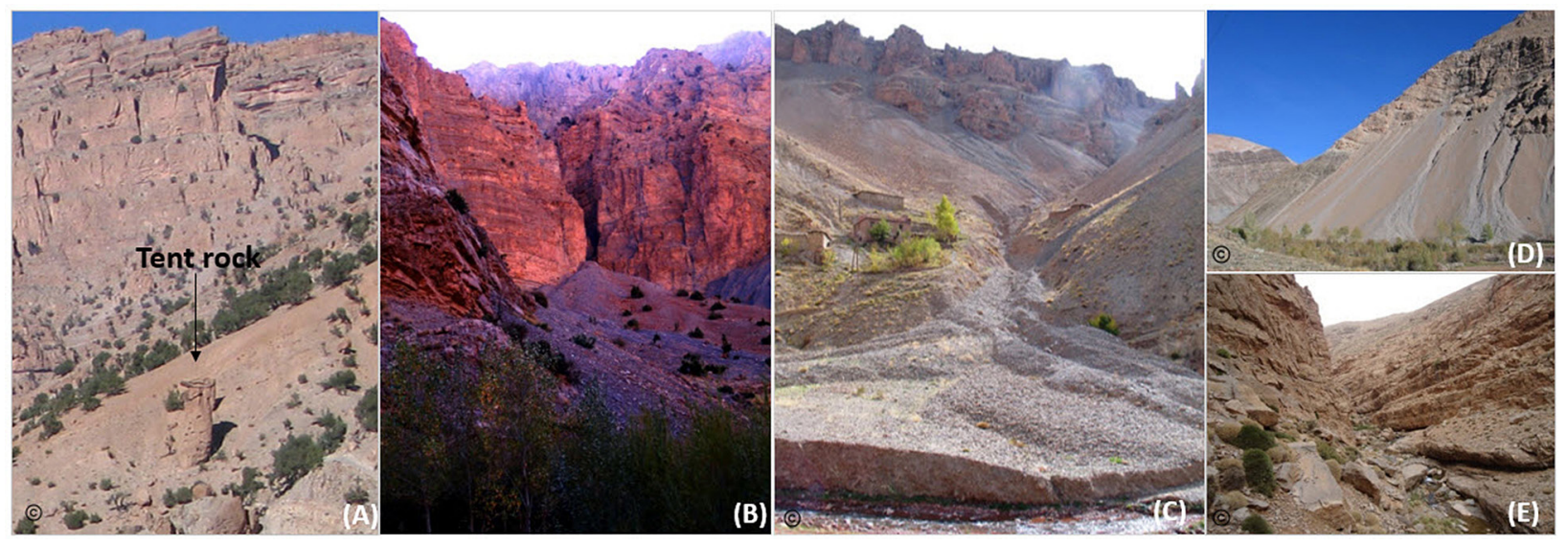

Fig. 11. The most notable geosites of the third geotouristic itinerary.

A) tent rock in Tlat-n-Tazart, B) scree cone in Tlat-n-Tazart, C) alluvial fan in Ichebaken, D) scree slopes in Amezri, E) canyons of High-Tessaout valley. 
of the Tignousti syncline and massive dolomitic limestone. On the left bank, deep valleys penetrate to the bottom of the Azghif plateau formed of thicker limestone layers and mixed mainly with marls (Couvreur 1988).

\section{Stop 3 in Amezri Village}

In this village, there are three remarkable geoheritage elements. One is scree slope on the left bank built of rock fragments derived from fault breccias, because the High-Tessaout valley above Amezri follow a fault zone related to alpine tectonic (Fig. 11D) (Couvreur 1988). Further, there are two alluvial on this right bank. Furthermore, in this village the valley meanders around the high cliffs in limestone rocks of the Lower Jurassic which overhang its two banks, generating a remarkable canyon with vertical cliffs whose height exceeds than $100 \mathrm{~m}$, and contrast abruptly with the smooth slopes which one will meet a little further upstream (Couvreur 1988).

\section{Stop 4 at the foot of Tessaout canyons}

The inaccessible canyons of High-Tessaout valley (Fig. 11E) are carved by the Tessaout River which flows along the axial zone of the perched syncline between the M'goun mountain in the south and Tarkeddid and Tignousti mountains in the north. Then it flows westward for a few $\mathrm{km}$ between 2950 and $2800 \mathrm{~m}$ a.s.l., in the opposite direction of the rise of the synclinal limb of Ighil Mgoun and Tarkeddid. The fluvial erosion on this synclinal limb generates one of the most notable canyons of the central High Atlas - HighTessaout canyons. This latter has been carved in the carbonates of Aït Bou Oulli and Jbel Rat rock formations of Lower Jurassic age. Its depth is more than $500 \mathrm{~m}$, and with a length of about dozen kilometres (Couvreur 1988).

\section{Conclusions}

The geotouristic map is a powerful medium of geotourism valorisations and promotion in mountain areas, especially in a country and continent not still sufficiently explored and promoted for geosites. This medium is a functional way to explain and promote the importance of geosites to the general public since it combines geomorphological and geological features and touristic information. The presented geotouristic map proves the great possibilities of using data, geological and geomorphological information and knowledge understandable for the average tourist. Skilful use of this knowledge in the field of geotourism can be used to better manage and protect places and areas valuable from the point of view of sustainable development. The final map dedicated to the geotourism promotion in Demnate and High-Tessouat valley includes the main geological and geomorphological geosites of the area, cultural sites and tourist information. The findings of our research lead us to the following conclusion: the study area has an excellent potential for geotourism development due to its rich geodiversity dating from the Precambrian to present. It also has a rich geomorphological heritage which has resulted from different morphogenetic agents giving rise to several geosites with high scientific values. Nevertheless, the local authorities are not yet aware of this rich geoheritage and its economic potential. So it is to be hoped that this work will positively influence local authority in designing and elaborating future strategies of development of this territory. This work has therefore integrated this richness into three geotouristic itineraries to publicize geosciences regarding its different geological and geomorphological geosites. It has been found that geotourism routes easily accessible, may positively increase the visitor number and help geology and geomorphology information gain more public recognition. Another main objective of this map and geotouristic itineraries is to attract more investments to improve the economic condition of the most disadvantaged communities and regions of Morocco and to increase the number of visitor, especially of those who profess geotourism. Moreover, the majority of these sites are not protected by legislation, so the aim is to add these geosites to the regional, national and international list of the geoheritage and their integration in the Geopark M'goun of central High-Atlas. Finally, it is hoped that this development will encourage the local inhabitants to value their heritage.

\section{Acknowledgements}

The authors would like to thank their colleagues P.Bachimon and P.Derioz of the UMR 
Espace dev (IRD) of Avignon University for their valuable insights and recommendations during field survey; mainly the choice of recommended touristic itineraries. The authors would like to express very great gratitude to two anonymous reviewers for their valuable and constructive suggestions during the development of this paper.

\section{References}

Badang D., Ali C.A., Komoo I., Leman M.S., 2016. Sustainable Geological Heritage Development Approach in Sarawak Delta, Sarawak, Malaysia. Geoheritage 9(4): 443-462. DOI 10.1007/S12371-016-0189-9.

Biron P., 1982. Moulasses rouges permo-triasique - Haut Atlas de Marakech. Tectonique synsédimentaire et métallogénie. Thèse 3rd cycle, Université de Grenoble, 170 pp.

Bouzekraoui H., Barakat A., Touhami F., Mouaddine A., El Youssi M., 2017. Inventory and assessment of geomorphosites for geotourism development: a Case study: The valley of Ait Bou Oulli (central High-Atlas, Morocco). Area. DOI 10.1111/area.12380

Bouzekraoui H., El Khalki Y., Mouaddine A., Lhissou R., El Youssi M., Barakat A., 2016. Characterization and dynamics of agroforestry landscape using geospatial techniques and field survey: a case study in central High-Atlas (Morocco). Agroforestry Systems 90(6): 965-978. DOI 10.1007/s10457-015-9877-8.

Brandolini P., Pelfini M., 2010. Mapping geomorphological hazards in relation to geotourism and hiking trails. In Regolini-Bissig, G., Reynard, E. (Eds). Mapping Geoheritage 35:31-45.

Brocx M., Semeniuk V., 2007. Geoheritage and geoconservation history, definition, scope and scale. Journal of The Royal Society of Western Australia 90: 53-87.

Castaldini, D., Valdati, J., Ilieş, D. C., Chiriac C., with contributions by Bertogna I., 2005. Geotourist map of the Natural Reserve of Salse di Nirano (Apennines of Modena, Northern Italy. Il Quaternario, Italian Journal of Quaternary Sciences 18(1): 245-255.

Comănescu L., Nedelea A., Robert D., 2013. The geotouristic map-between theory and practical use. Case study- the central sector of the Bucegi Mountains (Romania). GeoJournal of Tourism and Geosites 11:16-22.

Comănescu L., Nedelea A., Stănoiu G., 2017. Geomorphosites and geotourism in Bucharest city center (Romania). Quaestiones Geographicae 36(3): 51-61. DOI 10.1515/ quageo-2017-0029.

Coratza P., Ghinoi A., Piacentini D., Valdati J., 2008. Management of geomorphosites in high tourist vocation area: an example of Geo-hiking maps in the Alpe di Fanes (Natural Park of Fanes-Senes-Braies, Italian Dolomites). GeoJournal of Tourism and Geosites 2(2): 6-117.

Coratza P., Regolini-Bissig G., 2009. Methods for mapping geomorphosites, In Reynard E., Coratza P., Regolini-Bissig G. (eds), Geomorphosites. München, Pfeil Verlag 89103.

Couvreur G., 1988. Essai sur l'évolution morphologique du Haut-Atlas central calcaire (Maroc). Notes et mémoires $d u$ Service géologique du Maroc 318.

Dowling R.K., 2011. Geotourism's global growth. Geoheritage 3: 1-13.
El Wartiti M., Malaki A., Zahraoui M., Di Gregorio F., De Waele J., 2009. Geosites and touristic development of the north-western Tabular Middle Atlas of Morocco. In: Marini A. (ed.), Desertification and Risk Analysis Using High and Medium Resolution Satellite Data. Springer Netherlands, Tozeur Tunesia: 143-159.

Erhartič B., 2010. Conserving geoheritage in Slovenia through geomorphosite mapping. Géovisions 35: 47-63.

Errami E., Schneider G., Ennih N., Randrianaly H.N., Bendaoud A., Noubhani A., Norman N., Allan M., Vasconcelos L., Costa L., Al-Wosabi M., Al-Subbary A., Mabvuto-Ngwira P., Okunlola G., Lawal Halliru S., Andrianaivo L., Siby S., Ketchemen B., Gauly M., Hassine M., Azki F., Juliette T., Lattrache K., Omulo M, Bobrowsky P., 2015. Geoheritage and Geoparks in Africa and the Middle-East: Challenges and Perspectives. In: Errami E., Brocx M., Semeniouk V. (eds), From Geoheritage to Geoparks, Case Studies from Africa and Beyond, Springer International Publishing, Cham: 3-23.

Farsani N.T., Coelho C.O.A., Costa C.M.M., Amrikazemi A., 2014. Geo-knowledge Management and Geoconservation via Geoparks and Geotourism. Geoheritage 6(3): 185-192.

Fuertes-Gutiérrez I., Fernández Martínez E., 2012. Mapping Geosites for Geoheritage Management: A Methodological Proposal for the Regional Park of Picos de Europa (León, Spain). Environmental Management 50: 789-806.

Górska-Zabielska M., Zabielski R., 2017. Potential values of urban geotourism development in a small Polish town (Pruszków, Central Mazovia, Poland). Quaestiones Geographicae 36(3): 75-86. DOI 10.1515/quageo-2017-0025. .

Grandgirard V., 1999. L'évaluation des géotopes. Geologia Insubrica 4: 59-66.

HCWCD [High Commission for Water, Forests and Combating Desertification], 2010 Dossier de base de la forêt d'Azilal. Rapport de synthèse, Maroc développement, High Commission for Water, Forests and Combating Desertification, Morocco, pp 142.

Hose T.A., 2011. The English Origins of Geotourism (as a Vehicle for Geoconservation) and Their Relevance to Current Studies. Acta geographica Slovenica 51(2): 343-360.

Ilieş D.C., Ilieş A., Herman G.V., Baias Ş., Morar C., 2011. Geotourist Map of the Băile Felix - Băile 1 Mai -Betfia Area (Bihor County, Romania. GeoJournal of Tourism and Geosites 2(8): 219-226.

Jenny J., Couvreur G., 1988. Carte géologique du Maroc au 1/100 000 feuille d'Azilal (haut atlas central): mémoire explicatif. Éditions du Service géologique du Maroc 339.

Jenny J., Le Marrec A., Monbaron M., 1981. Les couches rouges du jurassique moyen du Haut-Atlas central (Maroc). Corrélations lithostratigraphiques, éléments de dataion et cadre tectono-sédimentaire. Bulletin de la Société Géologique de France 7(6): 627-639.

Kubalíková L., Kirchner K., Bajer A. 2017. Secondary geodiversity and its potential for urban geotourism: a case study from Brno city, Czech Republic. Quaestiones Geographicae 36(3): 63-73. DOI 10.1515/quageo-2017-0024.

Michard A., Saddiqi O., Chalouan A., De Lamotte D.F., (eds) 2008. Continental evolution: The geology of Morocco: Structure, stratigraphy, and tectonics of the Africa-Atlantic-Mediterranean triple junction. Springer-Verlag, Berlin Heidelberg.

Migoń P., Goudie A., 2012. Pre-Quaternary geomorphological history and geoheritage of Britain. Quaestiones Geographicae 31(1): 67-79. DOI 10.2478/v10117-012-0004-x. 
Monbaron M., Monbaron J., 2015. La route des dinosaures: Iténiraires à travers le Géoparc M'goun, Haut Atlas, Maroc. Edition D'autre part, Suisse.

MTA [Ministère du Tourisme et de l'Artisanat], 2009. Vision 2020. Stratégie de développement touristique. Maroc. Online: www.orientalinvest.ma/telechargementfichiers/tourisme/Plaquette-2020-FR-bat.pdf (accessed 21 June 2017).

Nascimento M.A.L., Ruchkys U.A., Mantesso-Neto V., 2007. Geoturismo: um novo segmento do turismo no Brasil. Global Tourism 3(2): 41-64.

Nichols G., 2009. Sedimentology and stratigraphy (2 ed). John Wiley and Sons. p. 168.

Ollier C., 2012. Problems of geotourism and geodiversity. Quaestiones Geographicae 31(3): 57-61. DOI 10.2478/ v10117-012-0025-5.

Perret A., 2014. Géopatrimoine des trois Chablais: identification et valorisation des témoins glaciaires. Doctoral dissertation, Grenoble.

Regolini-Bissig G., 2010. Mapping geoheritage for interpretive purpose. Definition and interdisciplinary approach. In Regolini-Bissig, G., Reynard E., (eds). Mapping geoheritage, Lausanne, Institut de géographie. Géovisions 35: 1-13.

Regolini-Bissig G., 2012. Cartographier les geomorphositesObjectifs, publics et propositions méthodologiques, Institut de géographie. Géovisions 38: 316.

Regolini-Bissig G., Reynard E., (eds) 2010. Mapping Geoheritage, Lausanne, Institut de géographie. Géovisions 35: 1-13.

Reynard E., 2005. Géomorphosites et paysages. Géomorphologie: relief, processus, environnement 3: 181-188.

Reynard E., 2008. Scientific research and tourist promotion of geomorphological heritage. Geografia Fisica e Dinamica Quaternaria 31: 225-230.

Reynard E., Perret A., Bussard J., Grangier L., Martin S., 2015. Integrated Approach for the Inventory and Management of Geomorphological Heritage at the Regional Scale. The European Association for Conservation of the Geological Heritage. Geoheritage 8(1): 43-60.

Roch E., 1941. Carte géologique provisoire des régions de Demnat et de Télouet, Echelle au 1/200 000 - Notice explicative. Notes et Mémoires, Sérvice géologique, Maroc, 55.

Rodrigues M.L., Machado C.R., Freire E., 2011. Geotourism routes in urban areas: a preliminary approach to the Lisbon geoheritage survey. GeoJournal of Tourism and Geosites 8(2): 281-294.
Serrano E., Gonzalez-Trueba J.J., 2005. Assessment of geomorphosites in natural protected areas: the Picos de Europa National Park (Spain). Géomorphologie: relief, processus, environnement 3: 197-208.

Smith M.J., Griffiths J., Paron P., (eds.) 2011. Geomorphological Mapping: methods and applications. Elsevier, London.

Tahiri A., El Hadi H., Simancas J. F., González-Lodeiro F., Azor A., Martínez-Poyatos D., 2011. Geoheritage in Morocco: The Neoproterozoic Ophiolite of Bou Azzer (Central Anti-Atlas). Geoheritage. DOI 10.1007/s12371-0110032-2.

Thomas M.F., 2012. A geomorphological approach to geodiversity - its applications to geoconservation and geotourism. Quaestiones Geographicae 31(1): 81-89. DOI 10.2478/ v10117-012-0005-9.

Tricart J., Raynal R., Besançon J., 1972. Cônes rocheux, pediments, glacis. Annales de Geographie 343: 1-24.

Waele J.D., Melis M.T., 2009. Geomorphology and geomorphological heritage of the Ifrane-Azrou region (Middle Atlas, Morocco). Environmental Geology_58: 587-599.

Žáček V., Hradecký P., Kycl P., Ševčík J., Novotný R., Baroň I., 2017. The Somoto Grand Canyon (Nicaragua) a volcanic geoheritage site one decade after discovery: from field geological mapping to the promotion of a Geopark. Geoheritage 9(3): 299-309. DOI 10.1007/s12371-017-02218.

Zwoliński Z., 2004. Koncepcja mapy geoturystycznej (Geotouristic map concept). In: L.Kozacki, B.Medyńska-Gulij (eds), Kartografia tematyczna w kształtowaniu środowiska geograficznego, Bogucki Wydawnictwo Naukowe, Poznań: 293-301.

Zwoliński Z., 2009. The routine of landform geodiversity map design for the Polish Carpathian Mts. Landform Analysis 11: 77-85.

Zwoliński Z., Hildebrandt-Radke I., Mazurek M., Makohonienko M., 2017. Existing and proposed urban geosites values resulting from geodiversity of Poznań City. Quaestiones Geographicae 36(3): 125-149. DOI 10.1515/ quageo-2017-0031.

Zwoliński Z., Najwer A., Giardino M., 2018. Methods for assessing geodiversity. In: Reynard E., Brilha J. (eds), Geoheritage: Assessment, Protection, and Management, Elsevier, Amsterdam: 27-52.

Zwoliński Z., Stachowiak J., 2012. Geodiversity map of the Tatra National Park for geotourism. Quaestiones Geographicae 31(1): 99-107. DOI 10.2478/ v10117-012-0012-x. 